Studies KORYVANTES

Athens, Greece

Received: April $19^{\text {th }} 2018$

E-mail: perialos1@gmail.com

Accepted: April 30 2018

\title{
THE LOST TRIREME'S SAIL. WHY IT'S SO HARD TO FIND SAILS FROM ANCIENT GREEK WARSHIPS?
}

\begin{abstract}
Could an ancient sail survive into sea water environment and what happened to those staying off the coast, in dry conditions, when a naval battle was taking part? Was the factor that old sailclothes were used for other purposes such as bed covers, bags, clothes, etc, enough to make this lack of today's excavations or something else did also happened? This paper tries to shed some light on the questions above.
\end{abstract}

\section{KEYWORDS: ANCIENT SAILS, TRIREME SAILS, ANCIEN LINEN SAILS.}

Sails, in triremes, were consisted secondary propulsion system. Basic material for sail construction was linen (flax). Its use started in Egypt and spread throughout the Mediterranean as early as the second millennium BC (Black and Samuel, 1991: 220). It's large surface was made by many small pieces of linen stitched together with so much attention from the ancient sail

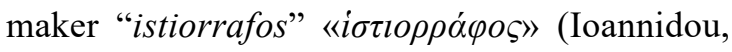
2014 and 2016: 30-31. It is said that, in order to make them stronger and protected against the thunderbold, the angles were forced with leather from seal or pelt of hyena (Plutarch, Table talk: 4, 2,1: 664c.) $)^{1}$.

Sails, from the Homer epics, had mostly white colour (Homer, Odyssey 2, 46) while flagships used red. It has been noted that black and grey sails existed as well (Simsas, 2006: 128).

1 Pliny also refers that thunder never strucks tents made of skin of seal, since seal is the only marine animal which is never struck. (Pliny, Natural History, 2, 56)

\section{PROCESSING AND WAVING OF FLAX}

Unfortunately no evidence have come to light about the processing and waving of flax in order to be a sail. Our information focused only for linen textile, in general, specially as cloth, and from two main sources: the ancient Egyptian texts (Blümer, 1912:193) and Plinius (Natural History: 19, 1618). Taking these into account we can assume that processing and waving of flax could achieved in a similar way for sails in ancient Greece as well. As Plinius mentioned (N. H: 19.3) they plunged the stalks of flax in the water that has been warmed in the sun. Then they submitted them to pressure with a weight. When the outer coat is loosened the stalks were sufficiently steeped. Then they turned with the heads downwards and left to dry in the sun. When thoroughly dried, they were beaten with a tow-mallet on a stone. After that

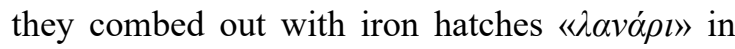
order to separate the short of the long hair. Long hair (ives), were spun with an instrument called

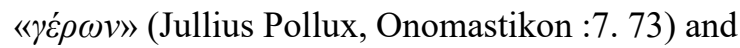




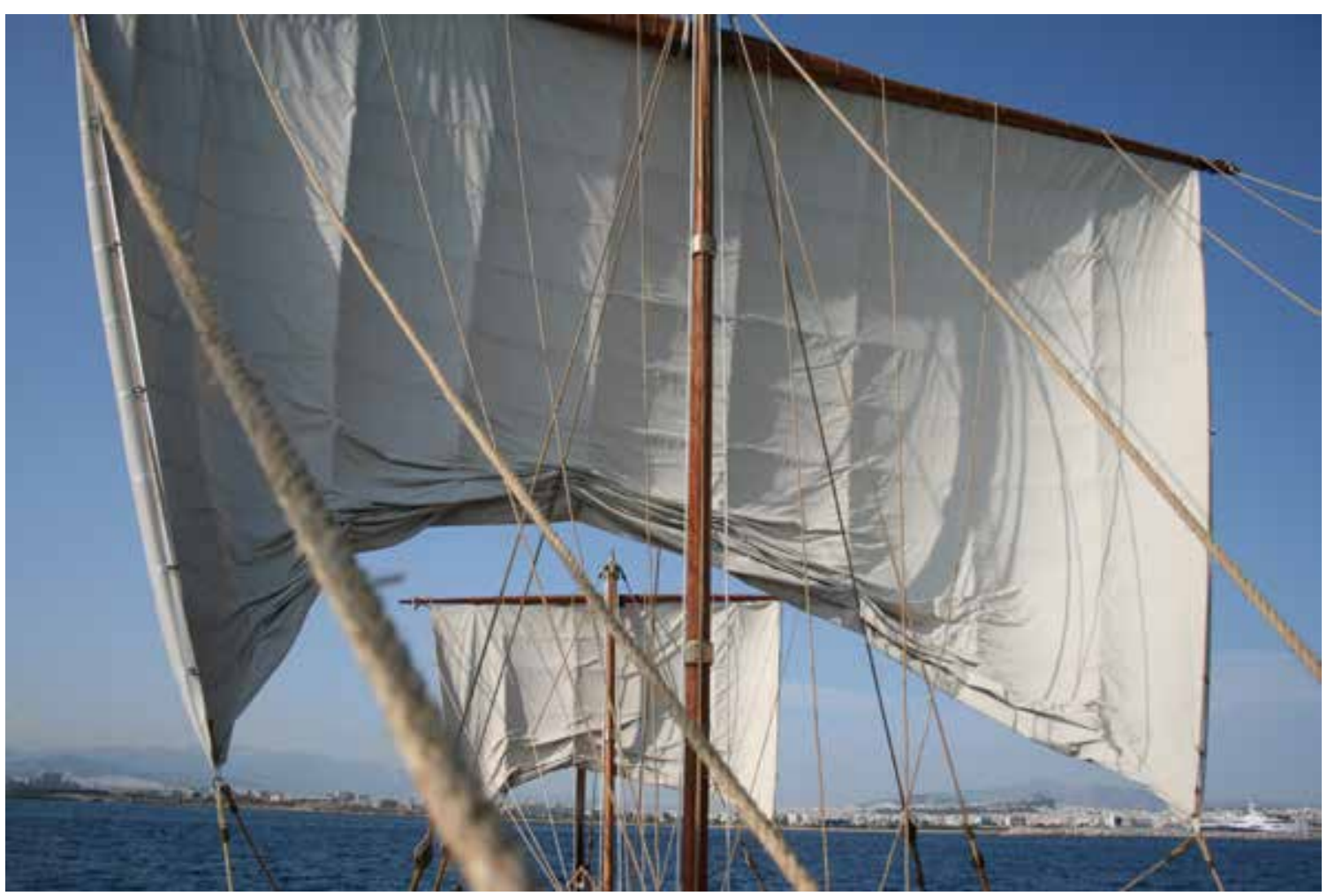

Fig. 1 Sails of trireme "Olympias" in Faliro Bay, Athens (Photo by Christy Emilio Ioannidou).

the thread that resulted was soaked in water and then beaten out upon a stone. After that it was wo-

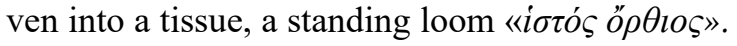
When the textile was ready was beaten again with heavy maces in order to improve its quality: "indeed, the more roughly it is treated the better it is" (Plinius, Natural History: 19, 3).

According to the spunning method that was used, thread had a specific twist. In Egypt linen threads have a twist similar in letter $\mathrm{S}$ while in Europe threads are $\mathrm{Z}$ twisted. In Greece $\mathrm{Z}$ twist remains stable from the prehistoric times until Roman Empire (Spantidaki, 2011: 76). Any difference can be marked that textiles in prehistoric times was made by double stranded thread -when two threads were twisted together but each one in different direction -while in classical times most of the textiles were made by single thread (Ibid).

Despite the opinion of older and foreign researcher who believed that Greece in ancient times had not sufficient production of flax $/$ linen $^{2}$ we can

2 Like for example: Rostovtzeff, M.I., The Social and find in ancient texts and archaeological preserved finds ${ }^{3}$ a great amount of evidences which support the opposite. Magnificent products, plain, embellished, embroidered ${ }^{4}$, with delicate threads, purple dyeing etc. (Spantidaki, 2011: 76). and references about the glorious linen textiles of Amorgos island (f.e. Thucydides: 4, 26, Aristophanis, Lysistrate: 735, Aeschines, Against Timarchos: 1, 97.)

Eaconomy History of the Hellenistic World, 3 vols. Oxford, 1941 and Francotte, H., L' industrie dans la Grèce ancienne, 2 vols., Bruxelles 1900-1901.

3 Like finds of textiles $\mathrm{Z}$ twisted from Bronze Age at excavation in Thera. See: Moulhérat, Ch., Spantidaki Y, and I. Tzachili, "Strings, ropes, nets and textiles from Akrotiri, Thera" [in Greek], Aracne, Hellenic Centre for Research and Conservation of Archaeological Textiles, 2004, 2, pp. 15-19. Among others, textile fragments of linen $\mathrm{Z}$ twisted, have been found: three of $5^{\text {th }} \mathrm{BC}$ in Maroussi, one of $4^{\text {th }} \mathrm{BC}$ in Hellinikon and one of $5^{\text {th }} \mathrm{BC}$ in Marathon. See: Y. Spantidaki and Ch. Moulhérat, "Textiles from Attica" [in Greek], Arachne, 2, pp. 5-12.

4 Like the fine textile, from Koropi, which is dated from classical antiquity and it is exhibit in Victoria and Albert Museum of London. See: J. Beckwith, "Textile fragments from classical antiquity: an important find at Koropi, near Athens", The Illustrated London News, 1954: 114-115. 


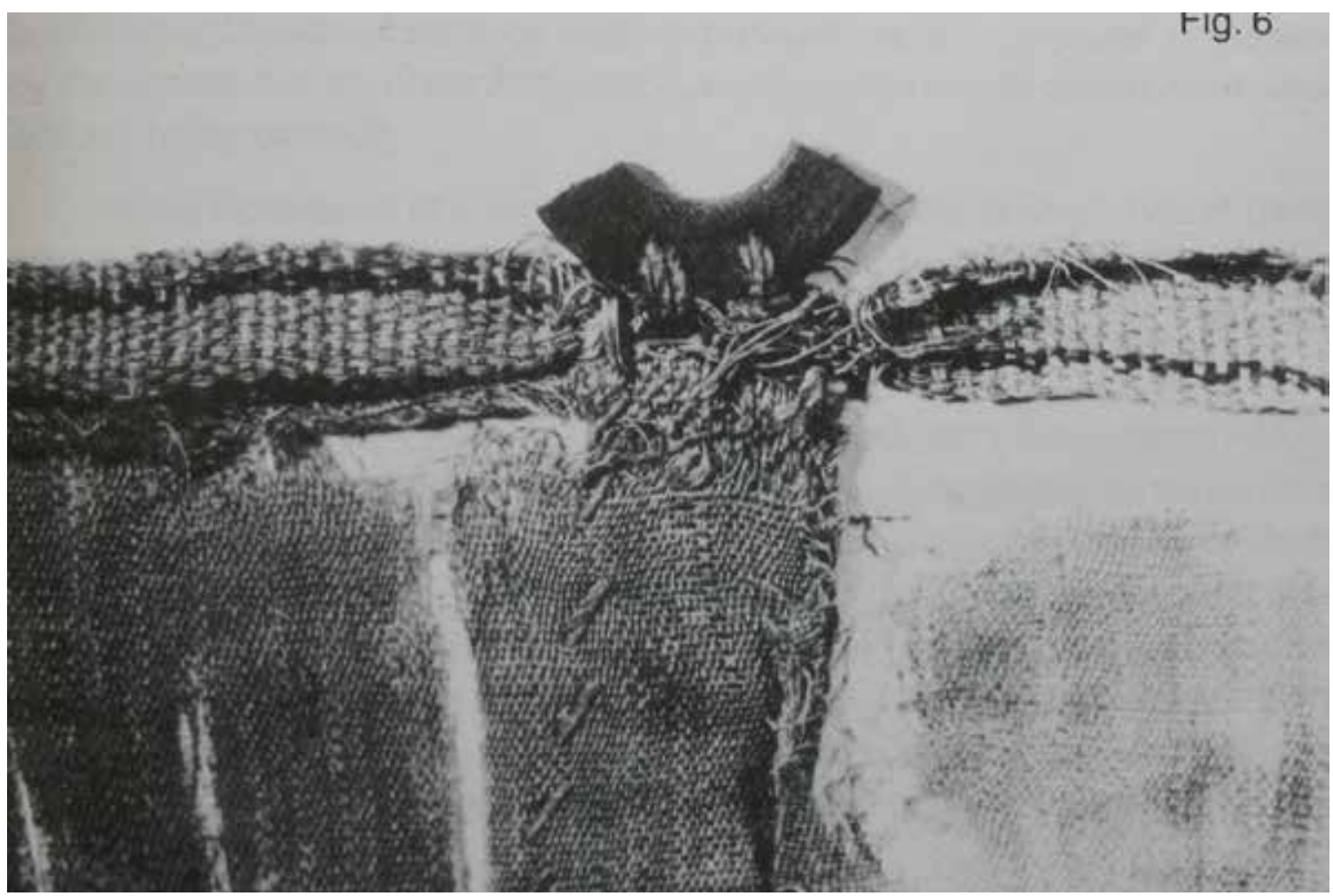

Fig. 2 Fabric of linen sail of Edfu with portion of brail ring. J. Rougé, "La Momie Contenait-elle les Fragments d' une Voile? (Nouvelle Arch. Mus. Nat. Lyon, 25, (1987) ref 10b, fig.2. in Black, E., "Where have all the sails gone?",

Tropis IV, HIPNT, 1996: 111.

or those of Colchis (Herodotos, History: 2.105, Strabo:11.17/C498) have left permanently their marks in history.

\section{LINEN TEXTILE AS SAIL}

When flax fibres become wet their strength increases (Cook, 1993:10/ Hahn, 2005: 1-42). rendering them suitable for maritime purposes such as ropes, sacks, fishing nets, cords, tents but mostly sail-clothes (Nosch, 2014: 17-42).

The lack of finds of sails in ancient wrecks lead us to the thought that sail clothes that they have been no more serviceable were used for other purposes such as bed covers, bags, clothes, etc (Black, 1996: 105).

This, actually, was a tactic of maritime people who wanted to minimize the cost of every naval equipment that was necessary for their trips. What is surprisingly interesting is the fact that sails were not recycled exclusively for naval purposes. Ar- chaeological finds appear that old sails were used for multiple purposes in the dry environment too.

As an example we can see the wool sail from Viking ship that was discovered at the roof of the northern church of Norway, Trondenes. This sail, is the earlier attested Scandinavian sail fragment (was radiocarbon dated between 1280 to 1420 AD) and was used to feel the gaps between the wooden planks of the church's roof (Bojer, 1994: 271-278). Another fascinating example is the discovery of a linen sail on an Egyptian mummy (Black, 1996: 103-112). This mummy, despite the fact that was found together with others in a temple at Edfu, Egypt, was the only who was wrapped in a linen sail. The sail has several horizontal reinforcing strips, $\mathrm{S}$ twisted, $5 \mathrm{~cm}$ wide each, to one which is attached a part of a wooden ring, a brail. It is at the Museum of Natural History of Lyon and Carbon-14 dated $( \pm) 150$ BC (James, 1988: 5/ Rougé, 1987: 91-6).

From the few samples of sails that have been found together with other naval instruments in 


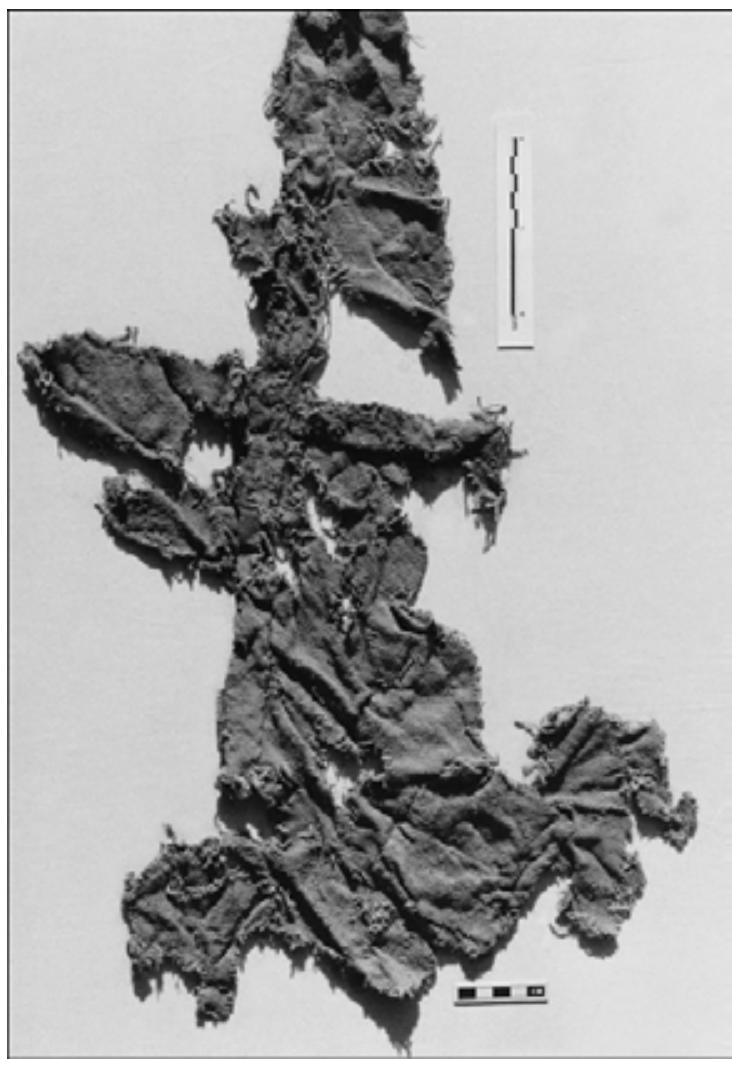

Fig. 3 Sail fragment from Berenike (97.103).

(Photo: J. P. Wild \& Berenike Project).

land territories, without been used for other purposes except for ship sails, are some pieces of linen sails that recovered from the excavations at ports of Berenike and Myos Hormos in Egypt during the years 2013-2014 together with bone and wood brailing rings dated at Early Roman period (Sidebothman, 2008: 305-324/ Wild and Wild, 2001: 211-220). These are parts from commercial vessel and most of the textiles are $Z$ twisted. Because of that $Z$ spun direction most believe that they couldn't considerate these textiles as Egyptian sails. Therefore, they adopted their Indian origin and claimed that they were presumably imported. It transpires, however, that the evidence from Berenike are not suggests ships of India but Mediterranean-style ships (Wild and Wild, 2001: 218). Mediterranean ships have one main mast and big square sails with reinforces. Indian ships, as we recognized them from Indian art, have two or three masts and their sails have no reinforcing strips (Schlingloff, 1988: 195-207).
According to my opinion, the origin of Berenike sail it should be put back on the table and second the Greek origin, because a) Greece and Egypt have at all times of history very good commercial bonds b) Greek linen sails manufactured according to Mediterranean way, with reinforcing strips and c) most of Greek textiles are $\mathrm{Z}$ twisted.

If actually Berenike and Myos Hormos sails are Greek then we will have some of the first finds of Greek sails of commercial ship. Until now no finds of sail from trireme or generally from Greek warship came up to light.

Returning to our subject, we realized that a great amount, of lost sails could occur due to the tactic of recycling older sails for other use.

During the $5^{\text {th }}$ and $4^{\text {th }}$ centuries, Athens confronted shortages of naval equipments, especially sails and ropes. Thus recycling method should be of great importance. But, could this fact provoke such a lack?

It is widely known that during naval battles triremes uses only the small sails while the big ones were kept up in the shore (Xenophon, Hellinica, 1.1.13, 6.2.27, Dion Cassius, Roman History, L, 31.2 and 33.2.) if time permitted, usually in specific storage houses " $\sigma \kappa \varepsilon v o \theta \dot{\eta} \kappa \eta "$

(Among others IG II2 1668). This fact conducts our thought in two main questions. What happened to the big sails which were kept safe into these storages and what to the smaller sinking to the bottom of the sea after a naval conflict?

\section{LACK OF TRIREME SAIL FINDS IN THE LAND}

As we mentioned above, big sails were kept in the land inside storage houses and special boxes (IG II2 1668). There are cases were the lack of these storages in a shore obliged people to create quick and rough constructions for keeping naval equipment. In such cases, textiles could be often suffer of attrition due to humidity, mould or 


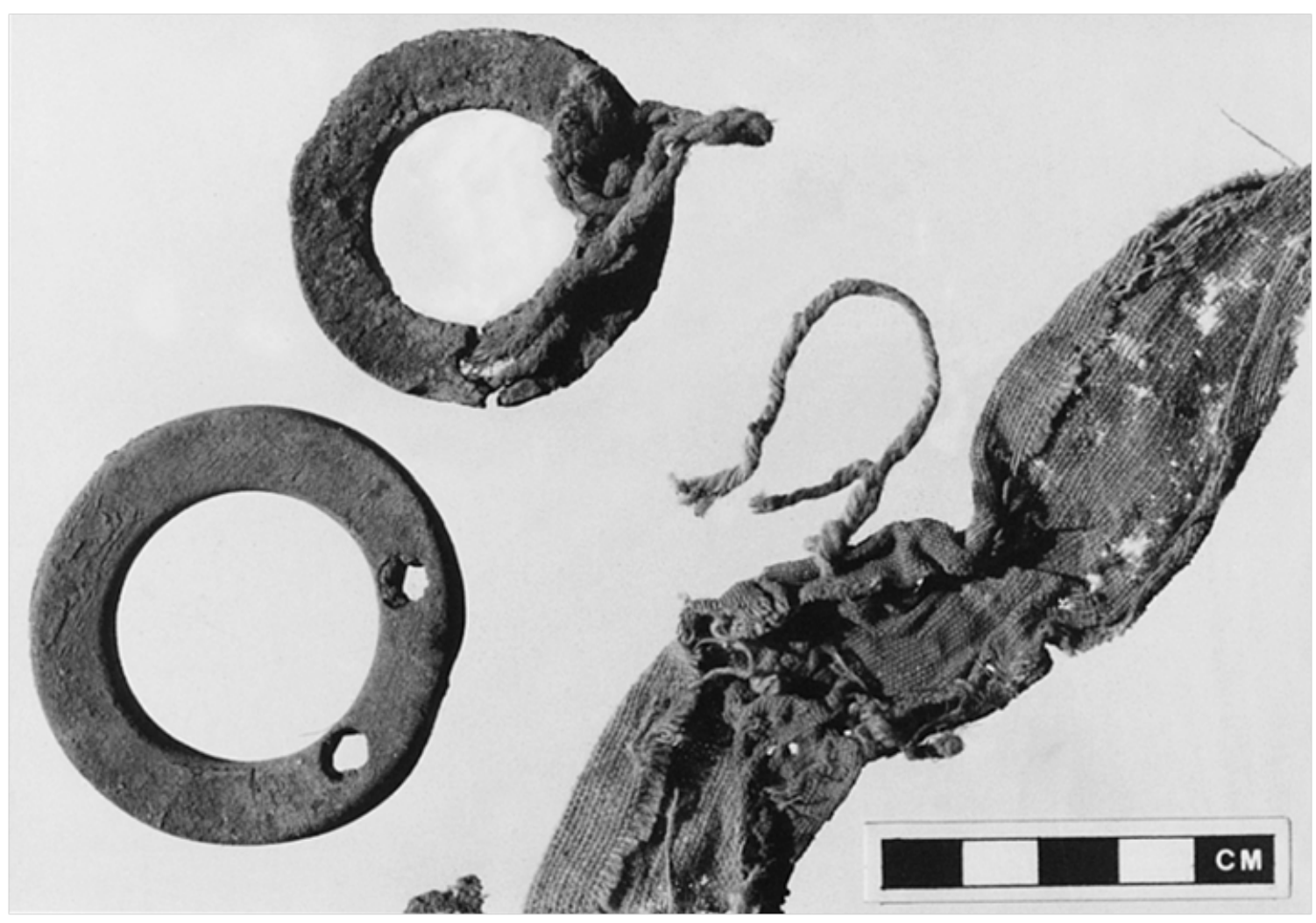

Fig. 4 Reinforcing strip (0758) and brailing rings from Berenike. (Photo: J. P. Wild \& Berenike Project).

would be an easy target of being stole. For the year 424BC we have a reference of mould, rotten

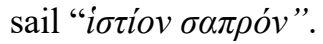

[I will cause you to be a trierarch expending your own money, with an old vessel, upon which you will never ease spending money or making repairs. And I will contrive that you get a rotten sail $]^{5}$.

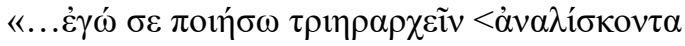

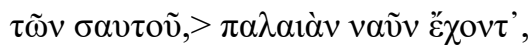

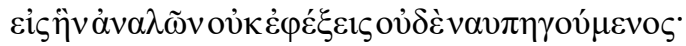

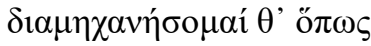

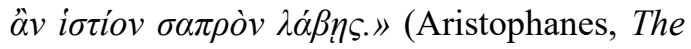
Knights, 912-918).

Places near the sea are vulnerable from humidity which favour bacteria and increase fungus.

These lasts provoke important changes in the properties of the fabric fibers. If sails were stored for long time, in places with high percent of humidity they were in great danger of being dam-

5 Translate into English by William James Hickie, 1853. aged and not usable any more from the appearance of bacteria and fungus.

As to the stole incidence its quite enough if we read an information of a work of Xenophon (Hellinica, 2, 1, 29) in which we learn that after the naval Battle of Aigos Potamoi, Athenian general Konon, escaped and reached Avarnis, where he found and took with him the big sails of Lysander's ships.

Stole of sails could make someone well off either the stealer was of the enemy's crew member or somebody who just wanted to sale them. For example, in Aristophanes work, a smuggler named Thorycion, was exporting various forbidden goods, among them sails, from Aegina to Epidauros (boarders of City States Athens and Peloponnesos):

[...who fort or fleet to the foe betrays; or, a vile Thorycion, ships away

Forbidden stores from Aegina's shores, to Epidaurus across the Bay 
Transmitting oarpads and sails and tar, that curst collector of five per cents; $]^{6}$.

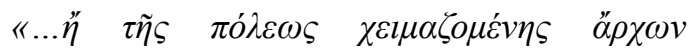
$\kappa \alpha \tau \alpha \delta \omega \rho о \delta о \kappa \varepsilon i \tau \alpha l$,

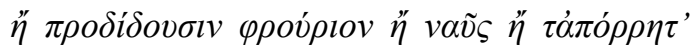
$\dot{\alpha} \pi \circ \pi \dot{\varepsilon} \mu \pi \varepsilon l$

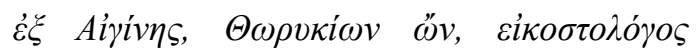

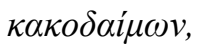

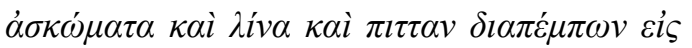

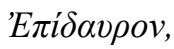

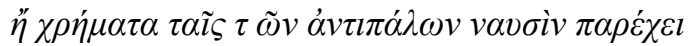

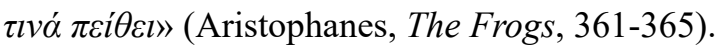

Looking into the Ancient Inscriptions we will be astonished at the fact of who else could steal naval equipment/sails. As Vincent Gabrielsen observes, throughout the fourth century the naval officials, captains and triêrarchoi "constantly and seriously draining the dockyards of public equipment" (Gabrielsen, 1994: 149/ Gabrielsen, 1995: 234-240). The reason can be easily interpreted. Some of them, sure enough have been lost during accidents/naval battles. But the rest have been removed for personal profit. Inscriptions testify an important lack of equipment which had been noted when triêrarchoi delivered their triremes to shipyards and the census was followed (Among others IG II2 1613, 1614 etc.).

By way of example in 353-352BC, 29 ships from Munychia lacked sails (IG II ${ }^{2} 1607,1609$ ). Most of the missing equipment was in the hands of officials and trierarchs (Gabrielsen, 1994: 146149). We can also distinguish names like somebody named Mnisikles Kolly who was obliged to return sails and ropes for 18 triremes (IG II ${ }^{2}$ $1622,420-431)$ and someone called Efthymachos who among plenty equipments was obliged to return small and big sails for 35 triremes (IG II2 1622, 443-477).

6 Translation into English by The Project Guttenberg E book of The Frog.

\section{LACK OF SMALL SAILS WHICH RESULT INTO THE SEA}

Considering that all the above mentioned issues consist of a mayor account of sails disappearance the only thing which left for being under microscope is the possibility a sail to be found under the water where the technical recycle or stole could not be existed.

Here, as an important tool functioning the work of Eve Black (1996: 103-112), who analyze the hostile environment by which the sail is surrounded at the bottom of the sea.

Fibers of cotton, linen, silk and wood as well, are composed of celluloses (long chains of sugar vulnerable to oxidation and microorganisms) and lignin. Lignin is the most important, after cellulose, ingredient of plant biomass, it limits the availability of cellulose, strengths and waterproofs the cell. Wood contains $20-30 \%$ lignin and has, therefore, survived at the sea's bottom, almost intact when protected by, or buried in sand or mud (Black, 1996: 106). For making ropes jute and sisal were used, which also have high lignin content. It is remarkable that parts or ropes have been found under the sea bottom, attached to anchors.

Unlikely, with linen happens something else. Row flax, contains up to 5\% lignin. But on retting, this amount is reduced and when comes at its final form, as textile, it has been left with high average of cellulose, completely vulnerable and at the mercy of the underwater elements (Black, 1996: 106).

According to modern calculations in a today's sea environment it is well known that a cotton rope will survive into the sea approximately 1-5 months, a cotton t-shirt 2-5 months and a pair of woolen socks 1-5 years 7 . In a study of Elene E. Peacock ${ }^{8}$ who puts textiles of linen, cotton, wool and silk in sand and water conditions showed that

7 U.S. National Park Service; Mote Marine Lab, Sarasota, FL and "Carbage In, Carbage Out", Audubon magazine, Sept/Oct. 1998.

8 The study was carry out at the Norwegian University of Science and Technology, Trondheim, Norway in 1994. 
linen was affected most severely (in 3-32 weeks), and the principal agent of deterioration was microbiological, although chemical attack cannot be rule out (Black 1996: 49-59).

Judging by all these its close enough to realize that in such a hostile environment, as sea water, if somebody, after a naval battle in classical times, wouldn't picked up the linen sail of the bottom of the sea no one could ever find it just after a period of one year as this would had completely disappeared.

\section{CONCLUSIONS}

Trireme sails, like any other ship type, couldn't survive in land mostly because of recycling or robbery. Sail's robbery usually acted by crew members of enemy's ships, merchants, captains, naval officers and trierarchs as well. On the other hand, sea environment was too hostile for linen textiles to preserve them for long time.

It will be most desirable a discovery of an ancient, not sacked, tomb, in which it will be found in storage an ancient trireme sail with its ropes and other nautical instruments.

\section{$* * *$}

Arheologija i prirodne nauke (Archaeology and Science) is an Open Access Journal. All articles can be downloaded free of charge and used in accordance with the licence Creative Commons - Attribution-NonCommercial-NoDerivs 3.0 Serbia (https://creativecommons.org/licenses/bync-nd/3.0/rs/.

Časopis Arheologija i prirodne nauke je dostupan u režimu otvorenog pristupa. Članci objavljeni u časopisu mogu se besplatno preuzeti sa sajta i koristiti u skladu sa licencom Creative Commons - Autorstvo-Nekomercijalno-Bez prerada 3.0 Srbija (https://creativecommons.org/licenses/bync-nd/3.0/rs/.

\section{BIBLIOGRAPHY}

\section{Black E. E. and Samuel D. 1991}

What Were Sails Made Of? Mariner's Mirror, (The Journal of The Society for Nautical Research), August, vol. 77: 220.

\section{Black, E. 1996}

Where have all the sails gone?, Tropis $I V$, HIPNT: 105.

\section{Blümer, H. 1912}

Technologie und Terminologie der Gerwebe und Künste bei den Griechen und Römen, 1: 193 fig. 76 in: Robert Flacelière, Fashion in Ancient Greece [in Greek], Athens, Papadima, 2002: 38.

\section{Cook, J. G. 1993}

Handbook of Textiles Fibres, vol 1, Natural Fibres, Merrow: 10.

\section{Gabrielsen, V. 1994}

Financing the Athenian Fleet, Public Taxation and Social Relations, Baltimore-London.

\section{Gabrielsen, V. 1995}

The Athenian Navy in Fourth Century BC. The Age of the Galley, Conway Maritime Press, London, pp.234-240.

\section{Godal, J. B., 1994}

Maritime archaeology beneath church roofs $\sigma \tau \mathrm{co}$. Westerdahl (Ed), Crossroads in Ancient Shipbuilding, Oxbow Monograph 40: 271-278. Oxford.

\section{Hahn, M.A. 2005}

Innovation in Linen Manufacture, Textile Progress 37/3: 1-42.

\section{Ioannidou, C. E. 2014}

Dictionary of Ancient Greek Naval Terminology

[In Greek], Historical Quest.

Ioannidou, C. E. 2016

Trireme. Tactics and Operational Environment in 
Ancient Greece [In Greek], Hellenic Navy, Naval History Department, Athens, pp. 30-31.

James, B. 1998

"The secrets of a mummy unwrapped", International Herald Tribune, March 24: 5.

Nosch, M. L. 2014

Linen textiles and flax in Classical Greece: provenance and Trade, Textile Trade and Textile Distribution in Antiquity, ed. Kerstin Dross-Krüpe, vol. 73, Wiesbaden: Harrassowitz Verlag: 17-42 (Phillipika).

\section{Peacock, E. E. 1996}

Biodegradation and characterization of water-degraded archeological textiles created for conservation research. International Biodeterioration and Biodegradation 36: 49-59.

\section{Rougé, J. 1987}

La Momie Contenait-elle les Fragments d' une Voile? Nouvelle Arch. Mus. Nat. Lyon, 25: 91-6.

\section{Schlingloff, D. 1988}

Studies in the Ajanta Paintings: Identifications and Interpretations, Delhi.

\section{Sidebothman, S.E., 2008}

Archaeological Evidence for Ships and Harbor Facilities at Berenike (Red Sea Coast), Egypt, Memoirs of the American Academy in Rome, Supplementary Volumes, Vol. 6, The Maritime World of Ancient Rome: 305-324.

\section{Simsas, M. 2006}

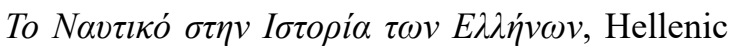
Navy, Naval History Department, Athens, (YIN/ ГEN), vol.1: 128.

\section{Spantidaki, S. 2011}

Is Textile-Making a Simple Matter? [In Greek], Archaeology and Arts, 95: 76.
Wild, F.C. and Wild, J. P. 2001

Sails from the Roman Port at Berenike, Egypt, International Journal of Nautical Archeaeology 30.2: 211-220.

\section{REZIME}

IZGUBLJENO JEDRO SA GRČKE

TRIJERE.

\section{ZAŠTO JE TEŠKO PRONAĆI} JEDRA SA GRČKIH RATNIH BRODOVA

\section{KLJUČNE REČI: ANTIČKA JEDRA, JEDRA TRIJERE, ANTIČKA JEDRA OD LANENOG PLATNA.}

Mogu li antička jedra da se sačuvaju u vodenoj sredini i šta se kasnije događa sa njima ukoliko se nađu na obali u suvoj sredini nakon završene bitke? Da li je platno korišćeno za jedra za grčke vojne brodove nalazilo kasnije drugu namenu, poput prekrivača za krevete, torbe, odeću itd. Da li se na taj način može pravdati nedovoljna istraženost i nedostatak nalaza jedara. U ovom radu je učinjen pokušaj da se bliže rasvetli ovaj problem i dobije mogući odgovor na pitanje ostataka jedara sa grčkih ratnih brodova. 